\title{
Inclusions and Microstructure of Steel Weld Deposits with Nanosize Titanium Oxide Addition
}

\author{
Cuixin Chen, Haitao Xue, Huifen Peng, Liang Yan, Lei Zhi, and Sixu Wang \\ School of Materials Science and Engineering, Hebei University of Technology, Tianjin 300130, China \\ Correspondence should be addressed to Cuixin Chen; karenccx@126.com
}

Received 1 November 2013; Accepted 13 February 2014; Published 18 March 2014

Academic Editor: Weichao Song

Copyright (C) 2014 Cuixin Chen et al. This is an open access article distributed under the Creative Commons Attribution License, which permits unrestricted use, distribution, and reproduction in any medium, provided the original work is properly cited.

Nanosize $\mathrm{TiO}_{2}$ particles were added directly into welding molten pool through electrode for the difficulty of accurate control of oxygen potential and production processing parameters. The characteristics of phase transformation and thermal behavior of inclusions for $\mathrm{Fe}-\mathrm{C}-\mathrm{Mn}-\mathrm{Si}-\mathrm{Ti}-\mathrm{O}$ system and $\mathrm{Fe}-\mathrm{C}-\mathrm{Mn}-\mathrm{Si}-\mathrm{TiO}_{2}$ system were analyzed. Results show that the added $\mathrm{TiO}_{2}$ particles are more helpful for the formation of $\mathrm{Mn}$-Ti-O complex inclusion and can induce the decrease of phase transformation temperature of austenite to ferrite. Intragranular ferrite can be obtained under the condition of continuous cooling transformation with cooling rate of $293 \mathrm{~K} / \mathrm{s}-373 \mathrm{~K} / \mathrm{s}$. The inclusions in steel welds are spherical in shape and mainly composed of $\mathrm{TiO}_{2}, \mathrm{Ti}_{3} \mathrm{O}_{5}, \mathrm{Ti}_{2} \mathrm{O}_{3}, \mathrm{MnO}$, and $\mathrm{SiO}_{2}$. The mean size of inclusions is $0.67 \mu \mathrm{m}$. These complex inclusions can supply a large number of nucleating cores for their precipitation at higher temperature, which will disturb the growth of columnar crystal during solidification. Moreover, Mncontaining titanium oxides will promote the transformation of austenite to intragranular ferrite for the formation of manganese depleted zones in steel welds around oxides. So it can be concluded that nanosize titanium oxide added directly in welding molten pool can be effectively used to control phase transformation and achieve fine and favorable microstructure.

\section{Introduction}

Titanium is one of the most effective alloying elements to improve the mechanical properties of materials in steelmaking and welding metallurgy. This is because Ti-containing phases, such as $\mathrm{TiC}, \mathrm{TiN}, \mathrm{Ti}(\mathrm{CN}), \mathrm{TiO}_{x}$, and $\mathrm{MnTiO}_{x}$, can inhibit grain growth by Zener pinning effect resulting in grain refinement and can also act as the nucleation sites of acicular ferrite [1-4].Among these phases, the complex inclusions containing titanium oxide have been recognized as one of the most effective ones $[5,6]$. Titanium oxides such as $\mathrm{TiO}, \mathrm{TiO}_{2}$, $\mathrm{Ti}_{2} \mathrm{O}_{3}$, and $\mathrm{Ti}_{3} \mathrm{O}_{5}$ are all the potent nucleation cores during solidification and solid phase transformation for their high melting point and high stability. They have a relatively low misfit with ferrite in certain orientations and their presence in steels may therefore be expected to encourage substantial intragranular ferrite formation through lattice coherency [7]. In addition, the effectiveness of $\mathrm{TiO}$ for intragranular nucleation on inclusion is suggested to be due to a small disregistry with appropriately oriented ferrite [8] and that of $\mathrm{TiO}_{2}$ is suggested to be due to releasing oxygen to decarburize adjacent steel matrix, which is advantageous for ferrite nucleation [9]. In case of $\mathrm{Ti}_{2} \mathrm{O}_{3}$, the development of local manganese depleted zones (MDZs) around particles has been the most influential hypothesis $[5,10]$.

It should be noted that the size, shape, chemical composition, and distribution of inclusions containing titanium oxides have an evident effect on microstructure and properties of steel production. The suitable size and number of inclusions which can promote the formation of intragranular ferrite are, respectively, $0.25 \mu \mathrm{m}-0.8 \mu \mathrm{m}$ and $1.3 \times 10^{7}-1.0 \times$ $10^{6} \mathrm{~mm}^{-3}[8,11]$. So, the required oxygen content is $0.0015-$ $0.008 \%$ in titanium deoxidation steel [12]. Hiroki et al. studied the effect of oxygen content and cooling condition on microstructure. The results showed that more inclusions will be obtained with the increase of oxygen content and cooling rate [13]. Moreover, the higher the cooling rate, the finer the inclusions [14]. So, titanium content and oxygen potential as well as production parameters are crucial to the size and quantity of inclusions. However, it is difficult to control these parameters. So, an alternative method in which oxide was 


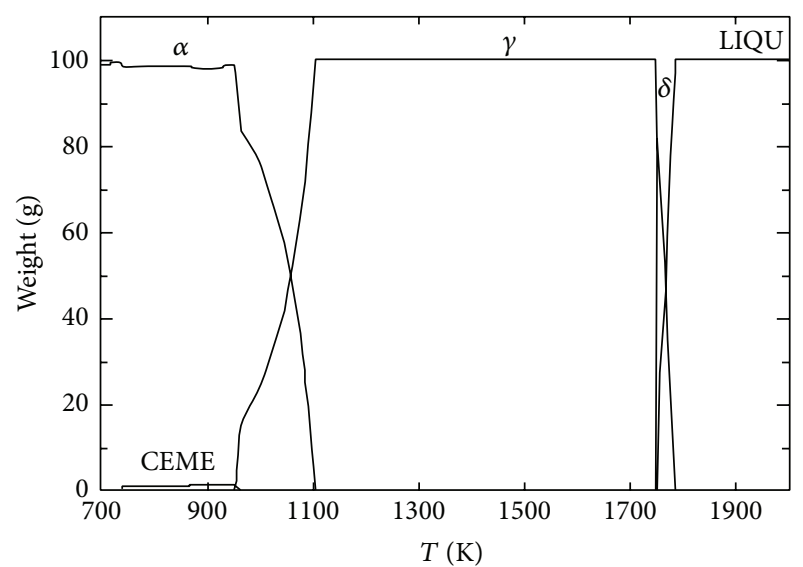

(a)

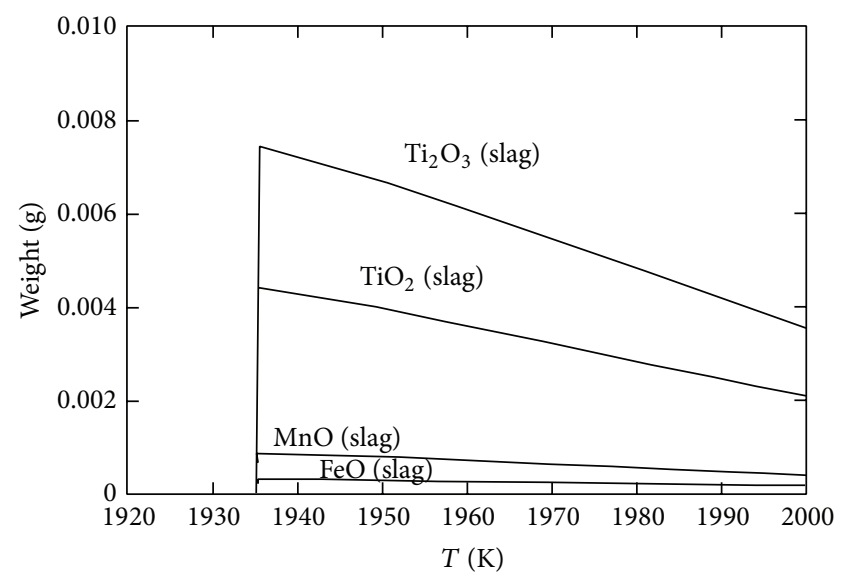

(c)

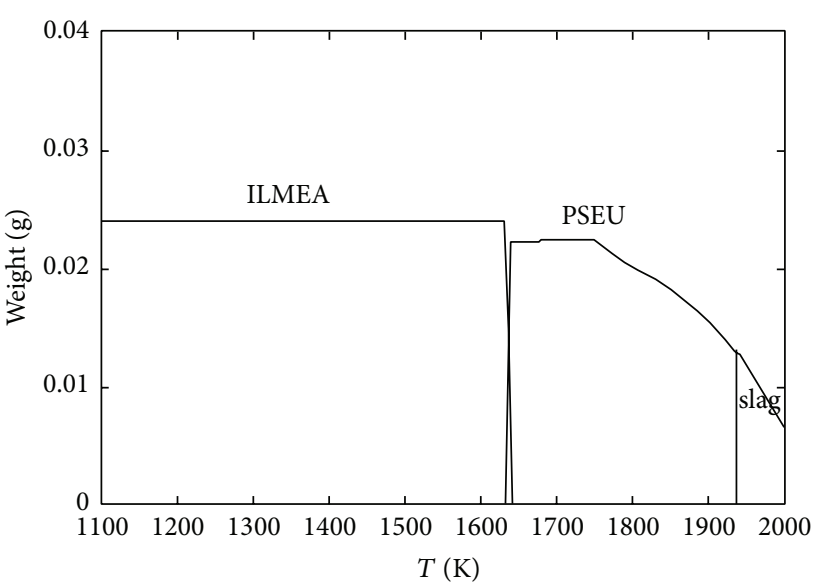

(b)

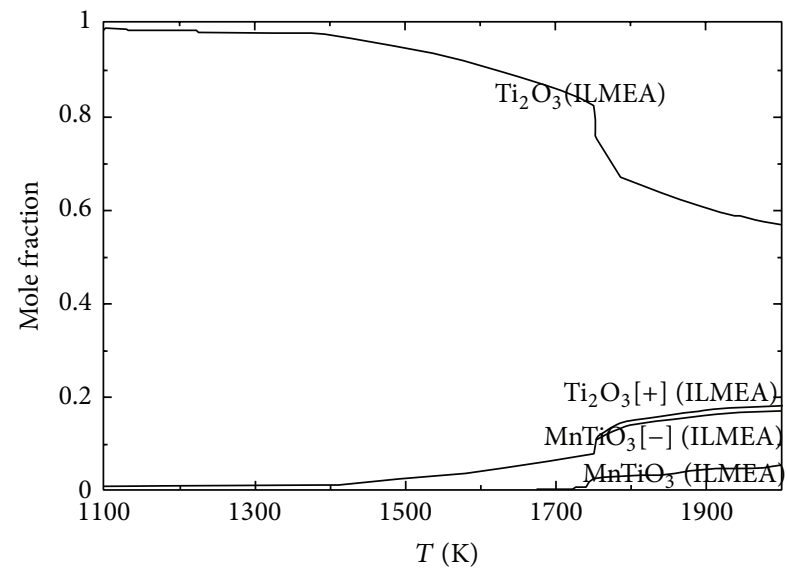

(d)

FIGURE 1: Phase transformation and inclusions of Fe-Mn-Si-Ti-O system (a) phase transformation, (b) solid solution, (c) slag, and (d) ILMEA.

added directly into molten welding pool through electrode coating was adopted in this study.

The purpose of this study is to analyze the effect of oxide addition on the thermodynamics and kinetics behavior of inclusions and phase transformation for low alloy high strength steel welds.

\section{Experimental Work}

A low alloy rolling steel with compositions of $0.12 \%$ C, $1.5 \%$ $\mathrm{Mn}$, and $0.5 \% \mathrm{Si}$ was adopted in the experiment. To avoid the quantitative control of oxygen potential and welding parameters, $0.2 \% \mathrm{TiO}_{2}$ particles with the mean size of $50-$ $100 \mathrm{~nm}$ were added directly in welding pool through electrode coating. For the agglomeration characteristics of nanomaterials, titanium oxides were pretreated with nanocoating and ultrasonic technology, which can ensure the uniform transition of oxide and improve the transfer coefficient.

The weld joints were prepared with the welding parameters of welding current of $120 \mathrm{~A}$, welding voltage of $30 \mathrm{~V}$, and welding speed of $3 \mathrm{~mm} / \mathrm{s}$. The dimension of base metal was
$200 \mathrm{~mm} \times 100 \mathrm{~mm} \times 10 \mathrm{~mm}$. The adopted welding machine was THERMALARC-MASTER 351.

Phase transformation of steel welds with Fe-Mn-Si-Ti-O system and $\mathrm{Fe}-\mathrm{Mn}-\mathrm{Si}-\mathrm{TiO}_{2}$ system under continuous cooling condition was analyzed by thermal simulating technology. The cooling rate in simulating test was $293 \mathrm{~K} / \mathrm{s}-373 \mathrm{~K} / \mathrm{s}$. This test was performed by Formastor IV digital automatic dilatometer.

For the detailed analysis of inclusions, acid dissolution method was adopted to collect inclusions in weld metal bases on ASTM E194290. Nuclepore polycarbonate membrane with the diameter of $47 \mathrm{~mm}$ and the pore diameter of $0.08 \mu \mathrm{m}$ was used in this test. First, three grams of weld metal was dissolved in $100 \mathrm{~mL}$ of hydrochloric acid at $353 \mathrm{~K}$. Then, the solution was filtered by polycarbonate membrane and the inclusions were filtered out followed by acid washing and rinsing by deionized water. Finally, the membrane with inclusions was dried.

GX-51 Olympus optical microscopy was employed to analyze microstructure. PHILIPS-XL30 scanning electron microscopy (SEM) with energy dispersive spectrometer (EDS) and JEM2010 transmission electron microscopy 


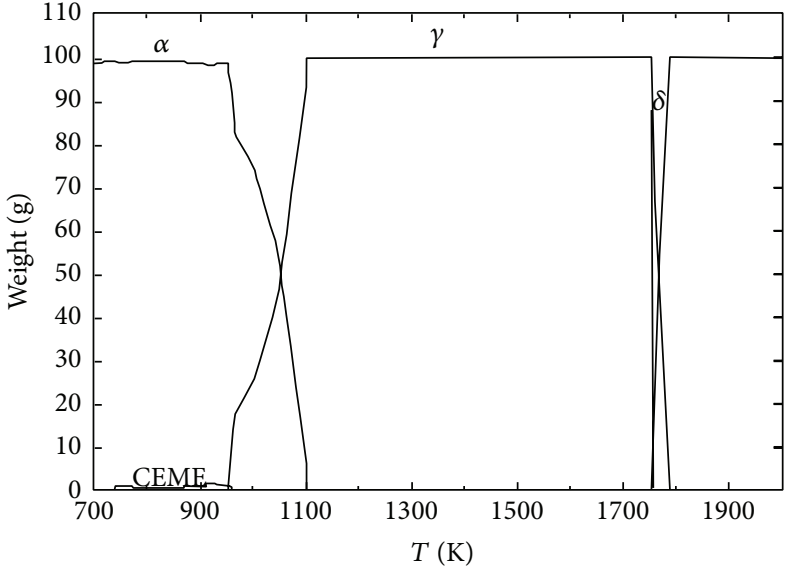

(a)

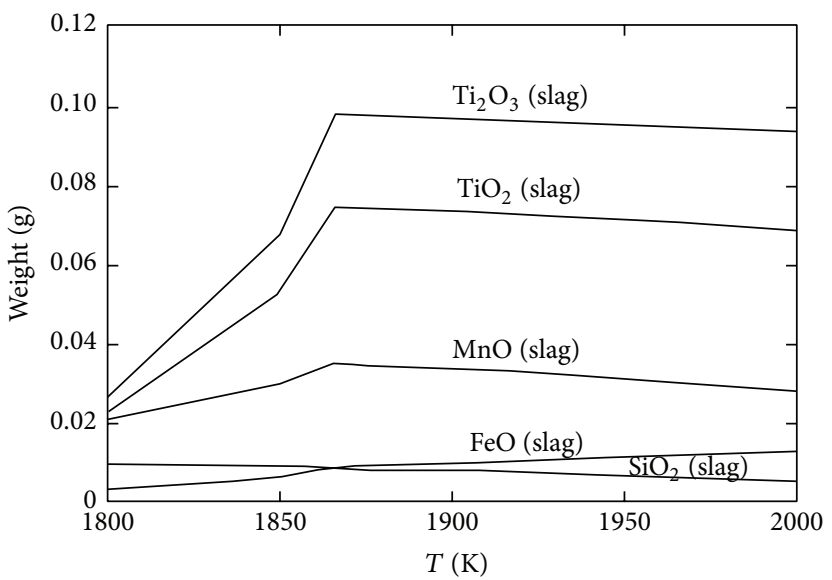

(c)

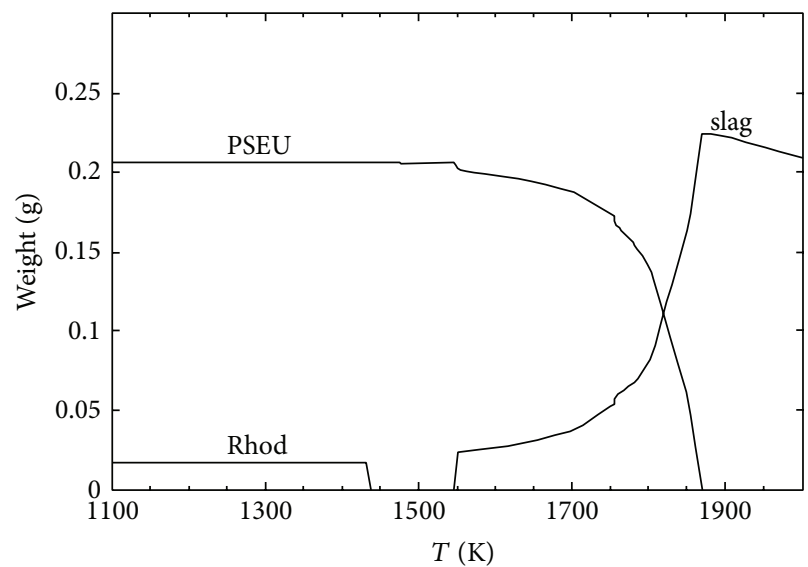

(b)

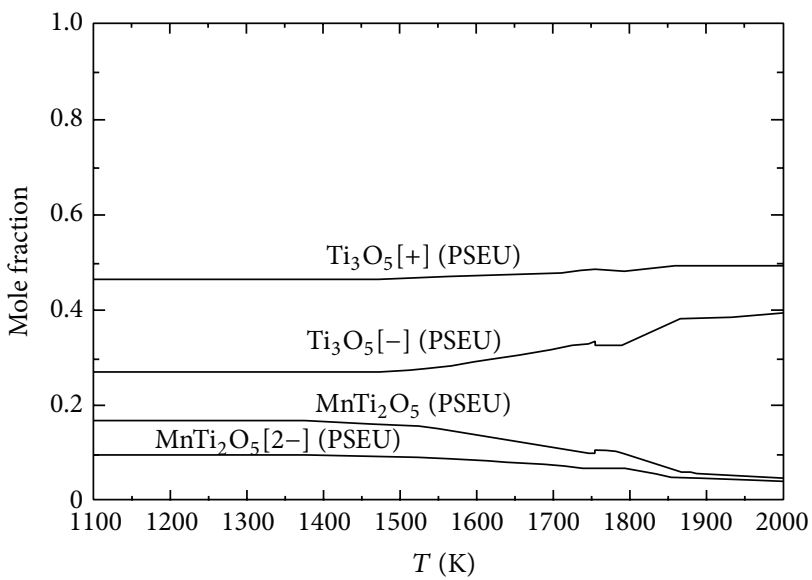

(d)

FIgure 2: Phase transformation and inclusions of Fe-Mn-Si-TiO 2 system (a) phase transformation, (b) solid solution, (c) slag, and (d) PSEU.

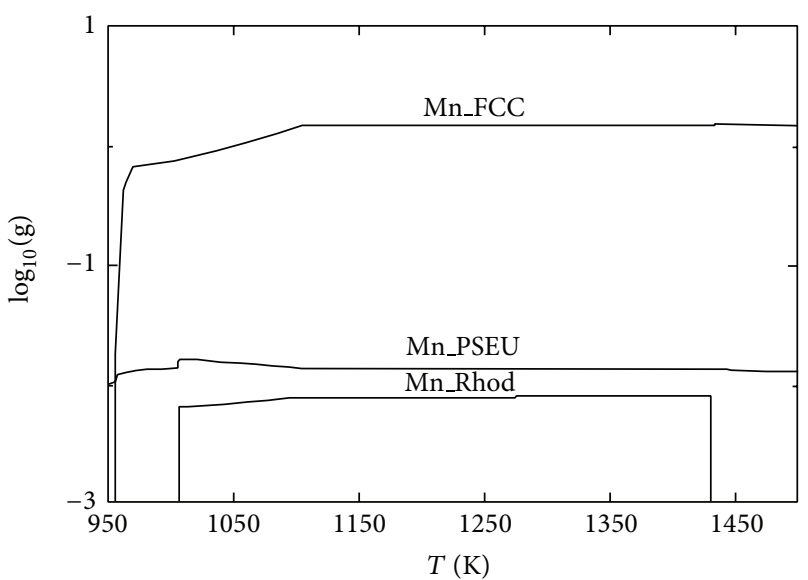

FIGURE 3: Manganese content change in FCC, PSEU, and Rhod.

(TEM) were used to analyze the morphology and chemical composition of complex inclusions.

\section{Thermodynamics Behaviors}

When titanium is added in liquid steel under certain oxygen content, the reactions are as follows [15]:

$$
\begin{array}{cc}
\mathrm{Ti}+2 \mathrm{O}=\mathrm{TiO}_{2} & \Delta G=-678132+235 \mathrm{~T} \\
2 \mathrm{Ti}+3 \mathrm{O}=\mathrm{Ti}_{2} \mathrm{O}_{3} & \Delta G=-1092504+358.1 \mathrm{~T} \\
3 \mathrm{Ti}+5 \mathrm{O}=\mathrm{Ti}_{3} \mathrm{O}_{5} & \Delta G=-1762656+571.2 \mathrm{~T},
\end{array}
$$

where $\Delta G$ is the standard Gibbs free energy change, J/moL.

Researches indicated that $\mathrm{Ti}_{3} \mathrm{O}_{5}$ is the most stable phase and then $\mathrm{Ti}_{2} \mathrm{O}_{3}$ under the same temperature and oxygen content condition. When oxygen content is lower, $\mathrm{TiO}$ and $\mathrm{TiO}_{2}$ cannot be found in steel liquid [15]. For the steel with $0.015 \% \mathrm{Ti}$ and $0.0018 \%-0.0077 \% \mathrm{O}$, the reaction product is $\mathrm{Ti}_{2} \mathrm{O}_{3}$ rather than $\mathrm{TiO}_{2}$ at $1873 \mathrm{~K}$ [16]. Only when the oxygen content is higher, $\mathrm{TiO}_{2}$ can form. The same results were also obtained by Zhuo et al. They indicated that when the oxygen activity is $2 \times 10^{-5}$, the most stable titanium oxide is $\mathrm{Ti}_{2} \mathrm{O}_{3}$ [17]. 


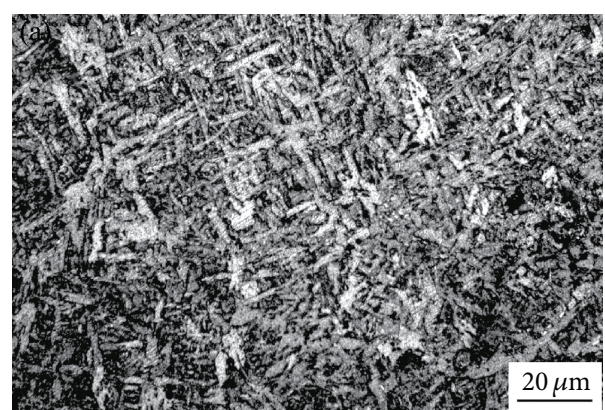

(a)

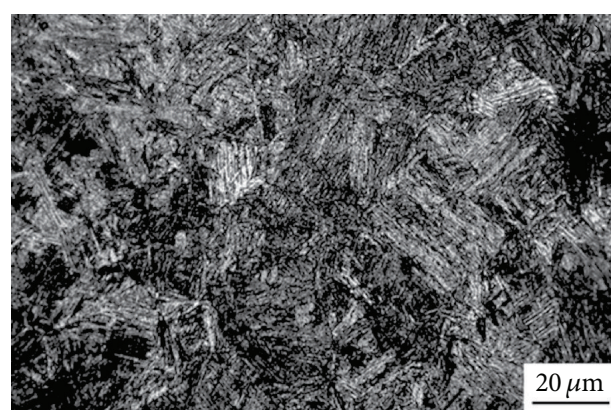

(b)

FIGURE 4: Microstructure of weld metal: (a) $0.2 \% \mathrm{TiO}_{2}$ added weld metal with $373 \mathrm{~K} / \mathrm{s}$ and (b) $0.05 \%$ Ti- $0.008 \% \mathrm{O}$ added weld metal with $373 \mathrm{~K} / \mathrm{s}$.

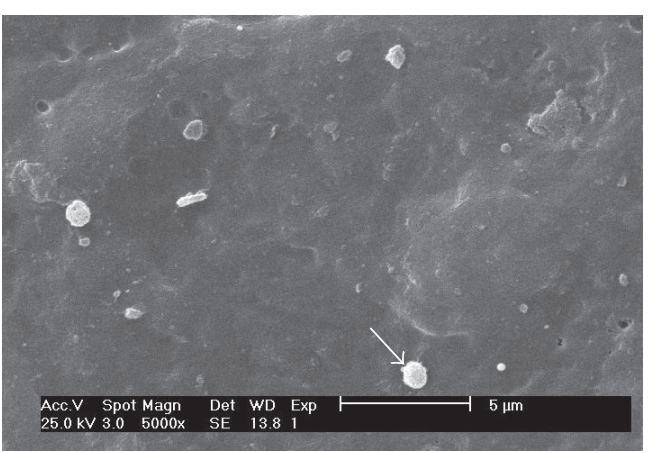

(a)

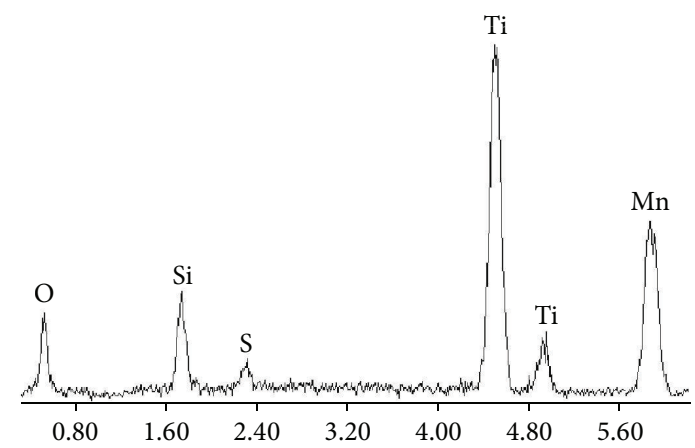

(b)

FIGURE 5: Morphology of inclusions (a) and the responding EDS results (b).

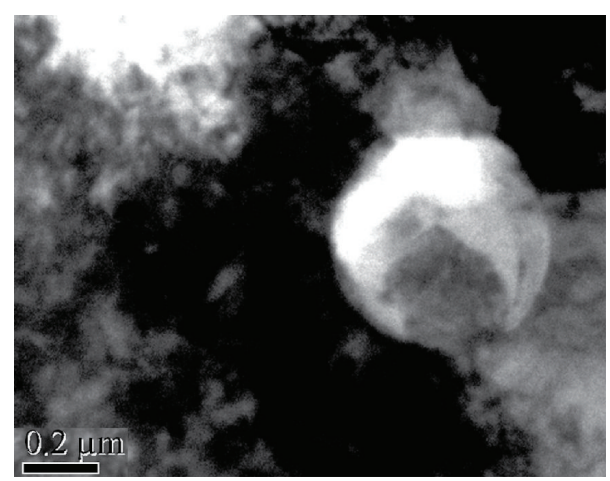

FIGURE 6: Inclusion in weld metal.

In addition, manganese in steel can affect the chemical composition of reaction products. If manganese exists, the reaction will be $[15,17]$

$$
\begin{gathered}
\mathrm{Mn}+\mathrm{O}=\mathrm{MnO} \quad \Delta G=-289027+125.8 \mathrm{~T} \\
\mathrm{MnO}+3 \mathrm{Ti}+5 \mathrm{O}=\left(\mathrm{MnTiO}_{3}-\mathrm{Ti}_{2} \mathrm{O}_{3}\right) \\
2 \mathrm{Mn}+3 \mathrm{O}+3 \mathrm{Ti}_{2} \mathrm{O}_{3}=2\left(\mathrm{MnTiO}_{3}-\mathrm{Ti}_{2} \mathrm{O}_{3}\right)
\end{gathered}
$$

For the steel with $1.65 \% \mathrm{Mn}$ and $0.01 \% \mathrm{Ti}$, when the oxygen content is $0.003 \%$, Mn-Ti-O complex inclusion will form during solidification. But when the oxygen content drops to $0.001 \%$, only titanium oxide can be found in steel [16]. So, the more stable inclusions forming in Fe-Mn-Ti-O melt were $\mathrm{Ti}_{3} \mathrm{O}_{5}, \mathrm{Ti}_{2} \mathrm{O}_{3}$, and $\mathrm{MnTiO}_{3}$ and $\mathrm{MnTiO}_{3}-\mathrm{Ti}_{2} \mathrm{O}_{3}$ can only be obtained with higher oxygen content.

When $\mathrm{TiO}_{2}$ was added directly in liquid steel, $\mathrm{TiO}_{2}$ with $\mathrm{Ti}^{4+}$ will be decomposed to titanium subchlorides and the reaction between $\mathrm{Mn}$ and titanium oxides can occur. The reactions are $[6,17]$

$$
\begin{gathered}
\mathrm{TiO}_{2}=\mathrm{Ti}+2 \mathrm{O} \\
2 \mathrm{TiO}_{2}=\mathrm{Ti}_{2} \mathrm{O}_{3}+\mathrm{O} \\
3 \mathrm{TiO}_{2}=\mathrm{Ti}_{3} \mathrm{O}_{5}+\mathrm{O} \\
\mathrm{Mn}+\mathrm{O}+2 \mathrm{TiO}_{2}=\mathrm{MnTi}_{2} \mathrm{O}_{5}
\end{gathered}
$$

So, the inclusions are mainly composed of $\mathrm{Ti}_{3} \mathrm{O}_{5}, \mathrm{Ti}_{2} \mathrm{O}_{3}$, $\mathrm{TiO}_{2}$, and $\mathrm{MnTi}_{2} \mathrm{O}_{5}$.

For further understanding the characteristics of phase transformation and thermal behaviors of inclusions, the thermodynamics equilibrium calculation was carried out (as shown in Figures 1 and 2 and Table 1). The solution phases forming in Fe-Mn-Si-Ti-O system and Fe-Mn-Si$\mathrm{TiO}_{2}$ are as follows: (1) slag $\mathrm{Ti}_{2} \mathrm{O}_{3}-\mathrm{TiO}_{2}-\mathrm{MnO}$, (2) Allmeniter (ILME) $\mathrm{Ti}_{2} \mathrm{O}_{3}-\mathrm{MnTiO}_{3}$, (3) Pseudobrookite (PSEU) $\mathrm{Ti}_{3} \mathrm{O}_{5}-\mathrm{MnTi}_{2} \mathrm{O}_{5}$, (4) Titania-Spinel (TiSp) $\mathrm{MnTi}_{2} \mathrm{O}_{4}$, and (5) Rhodonite (Rhod) $\mathrm{MnSiO}_{3}$. 
TABle 1: The calculating transformation temperature of steel in Fe-Mn-Si-Ti-O system and Fe-Mn-Si-TiO ${ }_{2}$ system.

\begin{tabular}{lcccccc}
\hline Steel & $\begin{array}{c}\text { Slag starting } \\
\text { temperature }(\mathrm{K})\end{array}$ & $\begin{array}{c}\text { Liquid } \rightarrow \delta \text { starting } \\
\text { temperature }(\mathrm{K})\end{array}$ & $\begin{array}{c}\delta \rightarrow \gamma \text { starting } \\
\text { temperature }(\mathrm{K})\end{array}$ & $\begin{array}{c}\delta \rightarrow \gamma \text { finishing } \\
\text { temperature }(\mathrm{K})\end{array}$ & $\begin{array}{c}\gamma \rightarrow \alpha \text { starting } \\
\text { temperature }(\mathrm{K})\end{array}$ & $\begin{array}{c}\gamma \rightarrow \alpha \text { finishing } \\
\text { temperature }(\mathrm{K})\end{array}$ \\
\hline $\mathrm{Ti}+\mathrm{O}$ & 2042.8 & 1784.9 & 1752.7 & 1748.3 & 1108.1 & 954.5 \\
$0.2 \% \mathrm{TiO}_{2}$ & 2437.5 & 1785.5 & 1754.1 & 1751.3 & 1105.9 & 956.5 \\
\hline
\end{tabular}

TABLE 2: Microstructure and phase transformation temperature of weld metal with different cooling rate.

\begin{tabular}{|c|c|c|c|c|}
\hline \multirow{2}{*}{ Weld metal } & \multirow{2}{*}{ Cooling rate $(\mathrm{K} / \mathrm{s})$} & \multirow{2}{*}{ Microstructure } & \multicolumn{2}{|c|}{ Phase transformation temperature $(\mathrm{K})$} \\
\hline & & & Starting temperature & Finishing temperature \\
\hline \multirow{6}{*}{ Ti-O } & \multirow{3}{*}{293} & Ferrite & 1302 & 954 \\
\hline & & Bainite & 891 & 771 \\
\hline & & Martensite & 669 & 555 \\
\hline & \multirow{3}{*}{373} & Ferrite & 989 & 931 \\
\hline & & Bainite & 811 & 725 \\
\hline & & Martensite & 657 & 584 \\
\hline \multirow{2}{*}{$\mathrm{TiO}_{2}$} & 293 & Acicular ferrite & 987 & 782 \\
\hline & 373 & Acicular ferrite & 951 & 718 \\
\hline
\end{tabular}

For Fe-Mn-Si-Ti-O system, slag precipitates at $2042.8 \mathrm{~K}$. It is composed of $55.3 \% \mathrm{Ti}_{2} \mathrm{O}_{3}, 32.8 \% \mathrm{TiO}_{2}, 7.3 \% \mathrm{MnO}$, and a little quantity of other oxides (as shown in Figure 1(c)). With the decrease of temperature, PSEU formed at $1640 \mathrm{~K}-1940 \mathrm{~K}$ and then transformed into ILMEA at temperature lower than $1640 \mathrm{~K}$ (as shown in Figure 1(b)). In contrast to Fe-Mn-Si-Ti$\mathrm{O}$ system, slag precipitates at higher temperature $(2437.5 \mathrm{~K})$ for $\mathrm{Fe}-\mathrm{Mn}-\mathrm{Si}-\mathrm{TiO}_{2}$ system. It mainly consists in $53.1 \% \mathrm{Ti}_{2} \mathrm{O}_{3}$, $29.1 \% \mathrm{TiO}_{2}, 6.7 \% \mathrm{MnO}$, and $13.1 \%$ other oxides (as shown in Figure 2(c)). Moreover, the solid solution is mainly composed of PSEU and Rhod (as shown in Figure 2(b)). This indicated that $\mathrm{TiO}_{2}$ in liquid can promote the formation of $\mathrm{Ti}_{3} \mathrm{O}_{5}$ and $\mathrm{MnTi}_{2} \mathrm{O}_{5}$.

From Table 1, it can be seen that the temperature of solidification and phase transformation of $\delta \rightarrow \gamma$ for Fe-Mn$\mathrm{Si}^{-\mathrm{TiO}_{2}}$ system is higher than that of Fe-Mn-Si-Ti-O system. This is because there are more solid solutions (about $0.21 \%$

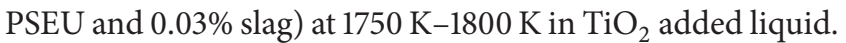
But only $0.023 \%$ PSEU exists in Fe-Mn-Si-Ti-O system. The existing particles in liquid can act as heterogeneous nuclei to decrease the critical nucleation energy resulting in the increase of temperature. In addition, the austenite in Fe-Mn$\mathrm{Si}-\mathrm{TiO}_{2}$ system has higher stability. The starting temperature of $\gamma \rightarrow \alpha$ is lower but the $\gamma \rightarrow \alpha$ finishing temperature is higher. The results show that $\mathrm{TiO}_{2}$ added system is helpful for the formation of intermediate microstructure.

At about $1100 \mathrm{~K}(\gamma \rightarrow \alpha$ transformation temperature $)$, the inclusions in $\mathrm{TiO}_{2}$ added system are $\mathrm{Ti}_{3} \mathrm{O}_{5}$ and $\mathrm{MnTi}_{2} \mathrm{O}_{5}$ (as shown in Figures 2(b) and 2(d)). However, the inclusions in $\mathrm{Fe}-\mathrm{Mn}$-Si-Ti-O system are ILMEA which mainly consist in $\mathrm{Ti}_{2} \mathrm{O}_{3} . \mathrm{Ti}_{3} \mathrm{O}_{5}$ is the most stable phase. Moreover, MnO$\mathrm{TiO}_{x}$ complex inclusions have been recognized as one of the effective inclusions for grain refinement and the nucleation of intragranular ferrite [18-21]. This is because titanium oxide can absorb some elements from substrate due to the existence of a large number of cation vacancies $[5,9]$. In addition, manganese with the ion radius of $0.070 \mathrm{~nm}$ has similar crystal structure to titanium $\left(\mathrm{Ti}^{+2} 0.090 \mathrm{~nm}, \mathrm{Ti}^{3+} 0.076 \mathrm{~nm}\right.$, and $\mathrm{Ti}^{4+}$ $0.068 \mathrm{~nm}$ ), which induce that manganese atoms are quite soluble in this structure. Therefore, it is reasonable to believe that the absorption of manganese from the steel matrix into titanium oxide particles dispersed in the steels is a probably thermodynamic process [18]. It has been known that the diffusivity of manganese in austenite between $1300 \mathrm{~K}$ and $1600 \mathrm{~K}$ is in the order of $10^{-14} \mathrm{~m}^{2} / \mathrm{s}$ and the solubility of manganese in cation site of titanium oxide phase is above 10 at $\%$ at $1473 \mathrm{~K}[19,20]$. Such a limited diffusivity of manganese in austenite and a large solubility of manganese in titanium oxide might contribute to forming and maintaining MDZs around titanium oxide. Figure 3 further confirms the result.

\section{Results and Discussion}

4.1. Continuous Cooling Transformation Characteristics. Table 2 shows the dilatometer test results. Under the cooling rate of $373 \mathrm{~K} / \mathrm{s}$, phase transformation temperature is in the range of $989 \mathrm{~K}$ to $584 \mathrm{~K}$ for $\mathrm{Ti}-\mathrm{O}$ system and $951 \mathrm{~K}$ to $718 \mathrm{~K}$ for $0.2 \% \mathrm{TiO}_{2}$ added case. In addition, the microstructure of Ti-O system is composed of martensite, bainite, and proeutectoid ferrite (as shown in Figure 4(b)). However, only intragranular ferrite forms in $\mathrm{TiO}_{2}$ added system (as shown in Figure 4(a)). The similar phenomenon occurs for the case with cooling rate of $293 \mathrm{~K} / \mathrm{s}$. The results indicate that, in nonequilibrium condition, $\mathrm{TiO}_{2}$ is favorable for the formation of intermediate temperature microstructure, especially for the case of rapid welding cooling condition.

4.2. Inclusions in Weld Metal. Figure 4 shows the morphology and chemical composition of inclusion in $0.2 \% \mathrm{TiO}_{2}$ added weld metal. Most of inclusions are spherical (as shown in Figure 5(a)) and the main chemical composition is $\mathrm{Ti}$, $\mathrm{Si}, \mathrm{O}, \mathrm{Mn}$, and $\mathrm{S}$ (as shown in Figure 5(b)). The complex inclusion has a black core with white surrounding (as shown in Figure 6). Chemical composition analysis shows that 


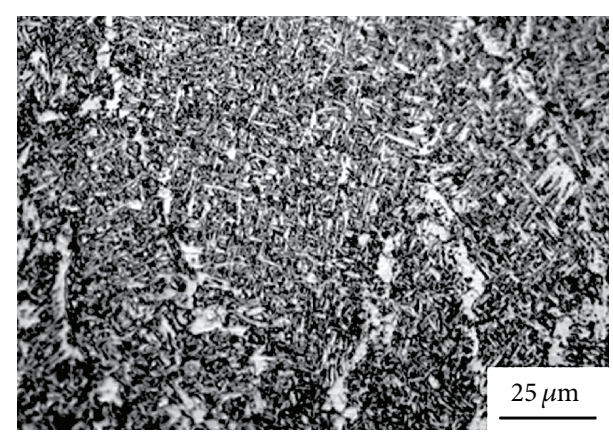

(a)

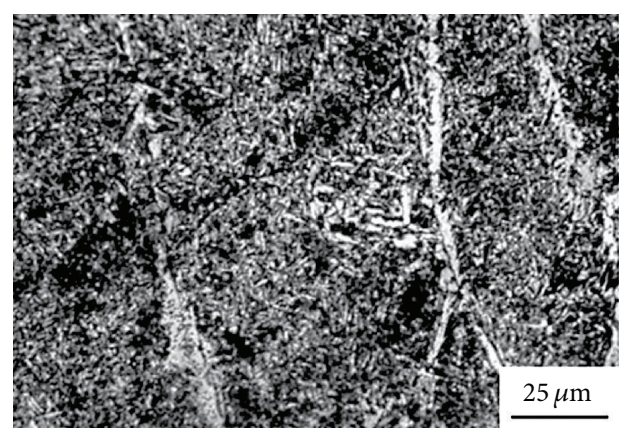

(b)

Figure 7: Crystal microstructure of weld metal: (a) $0.2 \% \mathrm{TiO}_{2}$ added and (b) $0.05 \% \mathrm{Ti}-0.008 \% \mathrm{O}$ added.

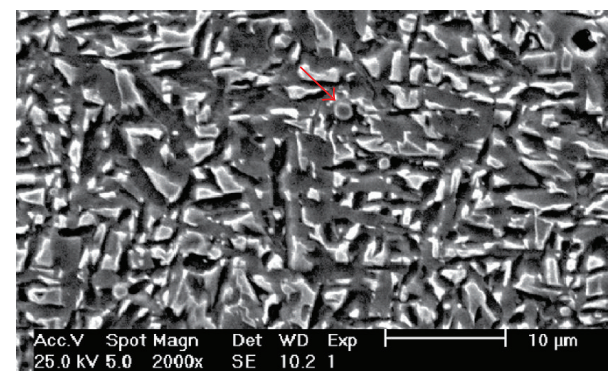

FIGURE 8: Intragranular ferrite.

the core is titanium oxide and the outer layer is manganese oxides and silicon oxide. In addition, the complex Ti-Mn-Si$\mathrm{O}$ inclusions have the mean size of $0.67 \mu \mathrm{m}$, which can act as nucleating sites to promote the solid phase transformation of $\gamma \rightarrow \alpha$. The results are consistent with calculated results.

4.3. Microstructure of Weld Metal. Figure 7 gives the microstructure of weld metal. From the results of 3 and 4.2, it can be seen that, during solidification, many suspending particles of $\mathrm{Mn}-\mathrm{Ti}-\mathrm{O}$ complex inclusions exist in liquid which can supply a large number of effective heterogeneous nucleation cores resulting in refining crystal microstructure by disturbing the growing direction of columnar crystal (as shown in Figure 7(b)). In subsequence cooling process, fine intragranular ferrite can be obtained in $\mathrm{TiO}_{2}$ added steel weld, as shown in Figures 7(a) and 8.

The inclusions in $\mathrm{TiO}_{2}$ added steel weld are mainly composed of $\mathrm{Ti}_{2} \mathrm{O}_{3}, \mathrm{Ti}_{3} \mathrm{O}_{5}$, and $\mathrm{MnTi}_{2} \mathrm{O}_{5}$. With the temperature dropping, the content of $\mathrm{MnTi}_{2} \mathrm{O}_{5}$ increases. The manganese content increases from $6.43 \%$ at $\gamma \rightarrow \alpha$ starting temperature $(1105.9 \mathrm{~K})$ to $6.86 \%$ at $\gamma \rightarrow \alpha$ at finishing temperature $(956.9 \mathrm{~K})$. EDS results show that the manganese content in weld metal surrounding the inclusion in Figure 8 is $1.45 \%$ which is lower than that $(1.63 \%)$ in weld metal far away from inclusions. So, MDZs are well developed around the particles dispersed in the steel weld matrix which will make nucleating driving force high and promote the formation of intragranular ferrite. Byun et al. indicate that the area fraction of intragranular ferrite has been related to $\mathrm{Mn}$ content in MDZs $[6,22]$. The lower the manganese content is, the higher the content of intragranular ferrite will be. So, the complex inclusions are favorable for the nucleation of intragranular ferrite, because they lead to elements redistribution.

\section{Conclusions}

The effects of $\mathrm{TiO}_{2}$ added directly in steel liquid on inclusions and phase transformation were studied. Thermodynamic calculation results show that $\mathrm{TiO}_{2}$ in liquid can promote the formation of stable solid solutions, $\mathrm{Ti}_{3} \mathrm{O}_{5}$ and $\mathrm{MnTi}_{2} \mathrm{O}_{5}$. In addition, the stability of austenite in $\mathrm{Fe}-\mathrm{Mn}-\mathrm{Si}-\mathrm{TiO}_{2}$ system is higher. The starting temperature of $\gamma \rightarrow \alpha$ is lower but the $\gamma \rightarrow \alpha$ finishing temperature is higher which is helpful for the formation of intermediate microstructure.

Under continuous cooling condition, only intragranular ferrite is found in $\mathrm{TiO}_{2}$ added steel welds with the cooling rate of $273 \mathrm{~K} / \mathrm{s}-373 \mathrm{~K} / \mathrm{s}$. The inclusions in steel welds are spherical and composed of $\mathrm{TiO}_{2}, \mathrm{Ti}_{3} \mathrm{O}_{5}, \mathrm{MnO}, \mathrm{SiO}_{2}$, and $\mathrm{MnS}$. The mean size is $0.67 \mu \mathrm{m}$. Moreover, the lower the temperature is, the more content of manganese is in complex inclusion. So, besides supplying nucleating sites, the complex inclusions can lead to the formation of MDZs in the border of inclusion due to the absorption of titanium oxide to manganese and cause deletion of austenite stabilizing elements in the matrix adjacent to the inclusions. Therefore, during $\gamma \rightarrow \alpha$ transformation, there is an increased thermodynamic driving force for intragranular ferrite formation in $\mathrm{TiO}_{2}$ added steel weld.

\section{Conflict of Interests}

The authors declare that there is no conflict of interests regarding the publication of this paper.

\section{Acknowledgments}

This research is financially supported by the National Natural Science Foundation (no. 51304059) and the Natural Science Foundation of Hebei Province (no. E2011202113). The authors would like to thank Professor X. Y. Song (Beijing University of Technology) and Professor K. Hack (GTT-Technologies, 
Herzogenrath, Germany) for their valuable discussions during the present study.

\section{References}

[1] Y. W. Cho, J. S. Byun, and J. H. Shim, "Effect of Ti addition on mixed microstructure of allotriomorphic and bainitic ferrite in wrought C-Mn steels," Materials Science Forum, vol. 426-432, no. 2, pp. 1511-1516, 2003.

[2] S. Hossein Nedjad and A. Farzaneh, "Formation of fine intragranular ferrite in cast plain carbon steel inoculated by titanium oxide nanopowder," Scripta Materialia, vol. 57, no. 10, pp. 937940, 2007.

[3] Z. B. Yang, F. Wang, S. Wang, and B. Song, "Intragranular ferrite formation mechanism and mechanical properties of nonquenched-and-tempered medium carbon steels," Steel Research International, vol. 79, no. 5, pp. 390-395, 2008.

[4] T. Pan, Z. G. Yang, C. Zhang, B. Z. Bai, and H. S. Fang, "Kinetics and mechanisms of intragranular ferrite nucleation on nonmetallic inclusions in low carbon steels," Materials Science and Engineering A, vol. 438-440, pp. 1128-1132, 2006.

[5] J. H. Shim, Y. W. Cho, S. H. Chung, J. D. Shim, and D. N. Lee, "Nucleation of intragranular ferrite at $\mathrm{Ti}_{2} \mathrm{O}_{3}$ particle in low carbon steel," Acta Materialia, vol. 47, no. 9, pp. 2751-2760, 1999.

[6] X. J. Zhuo, X. H. Wang, W. J. Wang, and H. G. Lee, “Thermodynamic calculations and experiments on inclusions to be nucleation sites for intragranular ferrite in Si-Mn-Ti deoxidized steel," Journal of University of Science and Technology, vol. 14, no. 1, pp. 14-21, 2007.

[7] T. Koseki and G. Thewlis, "Inclusion assisted microstructure control in C-Mn and low alloy steel welds," Materials Science and Technology, vol. 21, no. 8, pp. 867-879, 2005.

[8] S. St-Laurent and L. G. Esperance, "Effects of chemistry, density and size distribution of inclusions on the nucleation of acicular ferrite of CMn steel shielded-metal-arc-welding weldments," Materials Science and Engineering A, vol. 149, no. 2, pp. 203-216, 1992.

[9] J. M. Gregg and H. K. D. H. Bhadeshia, "Titanium-rich mineral phases and the nucleation of bainite," Metallurgical and Materials Transactions A, vol. 25, no. 8, pp. 1603-1611, 1994.

[10] J. H. Shim, J. S. Byun, Y. W. Cho, Y. J. Oh, J. D. Shim, and D. N. Lee, "Hot deformation and acicular ferrite microstructure in C-Mn steel containing $\mathrm{Ti}_{2} \mathrm{O}_{3}$ inclusions," ISIJ International, vol. 40, no. 8, pp. 819-823, 2000.

[11] F. J. Barbaro, P. Krauklis, and K. E. Easterling, "Formation of acicular ferrite at oxide particles in steels," Materials Science and Technology, vol. 5, no. 11, pp. 1057-1067, 1989.

[12] M. G. Li, S. B. Zheng, and Q. Zheng, "Oxides metallurgy," Shanghai Metal, vol. 27, pp. 55-60, 2005.

[13] G. Hiroki, M. Kenichi, and T. Kazuaki, "Effect of oxygen content on size distribution of oxides in steel," ISIJ International, vol. 35, no. 3, pp. 286-291, 1995.

[14] G. Hiroki, M. Kenichi, and T. Kazuaki, "Effect of Cooling rate on oxide precipitation during solidification of low carbon steels," ISIJ International, vol. 34, no. 5, pp. 414-419, 1994.

[15] H. G. Li, C. F. Wu, D. Zhao, S. B. Zheng, and Q. J. Zhai, "Thermodynamic analysis of ultra fine Ti oxide inclusion precipitation during steel solidification," Shanghai Metal, vol. 33, no. 2, pp. 36-39, 2011.
[16] W. Y. Xia, Y. C. Wang, M. L. Wang, and S. T. Qiu, "Behavior of oxide precipitation in solidification process for alumiumtitaniuni deoxidized steels," Journal of Iron and Steel Research, vol. 23, no. 8, pp. 11-15, 2011.

[17] X. J. Zhuo, X. H. Wang, W. J. Wang, and H. G. Lee, “Thermodynamic calculations and MnS solubility of Mn-Ti oxide formation in Si-Mn-Ti deoxidized steel," Journal of Iron and Steel Research, vol. 17, no. 2, pp. 10-17, 2010.

[18] J. H. Shim, J. S. Byun, Y. W. Cho, Y. J. Oh, J. D. Shim, and D. N. Lee, "Mn absorption characteristics of $\mathrm{Ti}_{2} \mathrm{O}_{2}$ inclusions in low carbon steels," Scripta Materialia, vol. 44, no. 1, pp. 49-54, 2001.

[19] W. C. Leslie, The Physical Metallurgy of Steels, MCGraw-Hill, New York, NY, USA, 1981.

[20] I. E. Grey, C. Li, and A. F. Reid, "Phase equilibria in the system $\mathrm{MnO}-\mathrm{TiO}_{2}-\mathrm{Ti}_{2} \mathrm{O}_{3}$ at $1473 \mathrm{~K}$," Journal of Solid State Chemistry, vol. 17, no. 4, pp. 343-352, 1976.

[21] Y. B. Kang, I. H. Jung, and H. G. Lee, "Critical thermodynamic evaluation and optimization of the $\mathrm{MnO}-\mathrm{SiO}_{2}-\mathrm{TiO}_{2}$ $\mathrm{Ti}_{2} \mathrm{O}_{3}$ system," Computer Coupling of Phase Diagrams and Thermochemistry, vol. 30, no. 3, pp. 226-234, 2006.

[22] J. S. Byun, J. H. Shim, Y. W. Cho, and D. N. Lee, "Non-metallic inclusion and intragranular nucleation of ferrite in Ti-killed CMn steel," Acta Materialia, vol. 51, no. 6, pp. 1593-1606, 2003. 

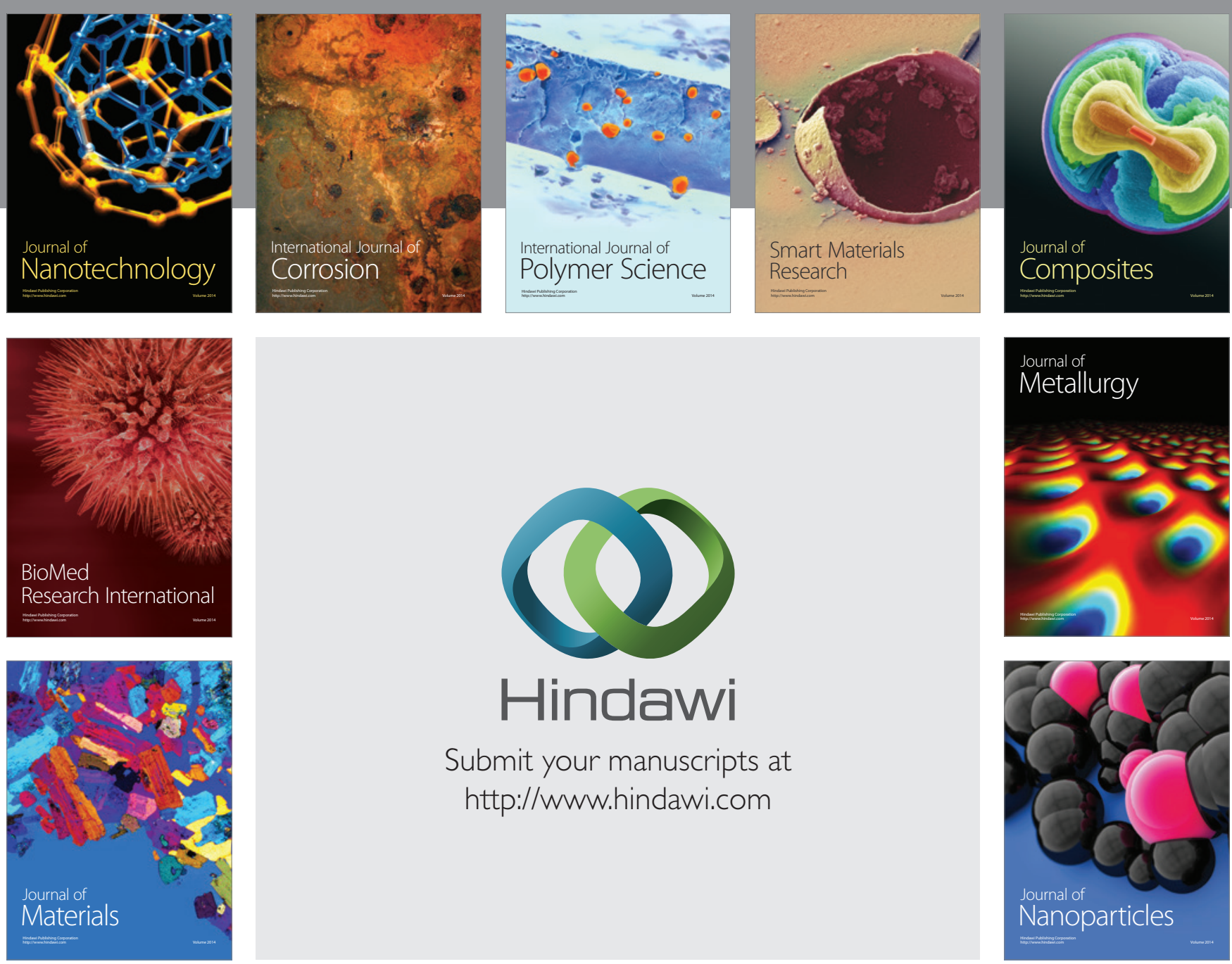

Submit your manuscripts at http://www.hindawi.com
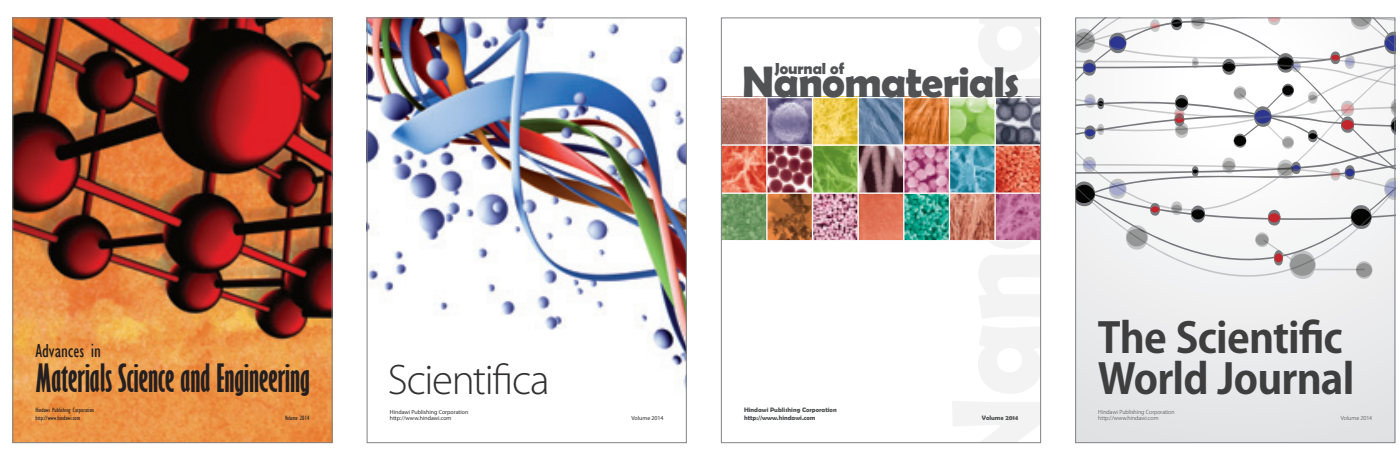

\section{The Scientific World Journal}
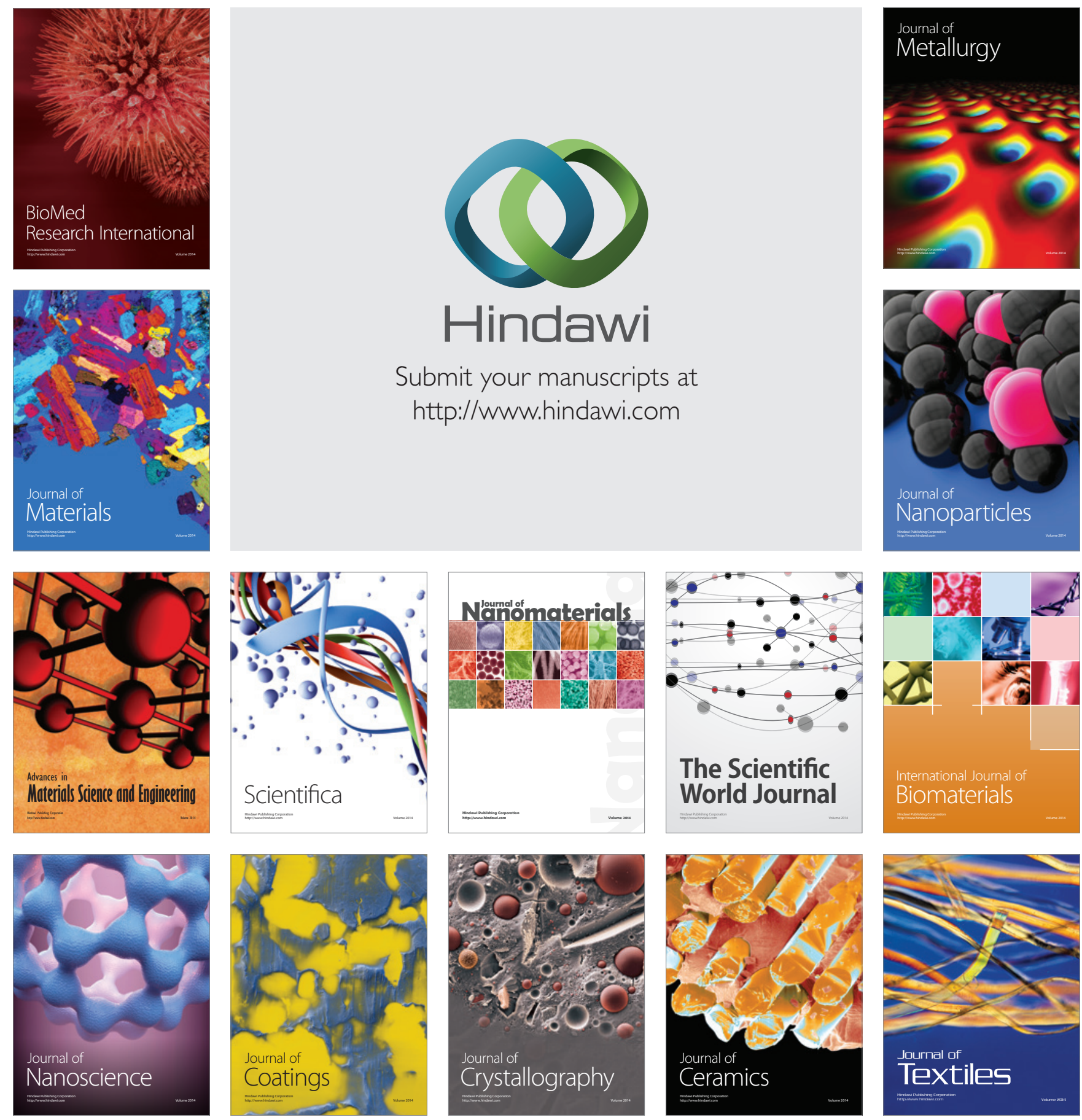